\title{
Refuse to be a fool
}

\author{
Ho Manh Toan
}

Phenikaa University

June 2, 2021

\begin{abstract}
"I work my whole life, I don't apologize, to take care of my family. And I refused to be a fool dancing on the strings held by all of those big shots. That's my life, I don't apologize for that. But I always thought that when it was your time, that you would be the one to hold the strings. Senator Corleone, Governor Corleone, something."

-Don Vito Corleone-
\end{abstract}

Science has been held on high moral ground, and precisely because of that, researchers have to try to satisfy everyone. They are universities, funders, industries, journals, publishers, editors, reviewers, and even the public. Universities and funders often demand prestigious studies in prestigious journals. Meanwhile, journals want submitted manuscripts to be novel and original, despite the fact that it could be the $54,560^{\text {th }}$ papers to write about a topic, and the journal is one in a few hundred journals in the same discipline. Editors and reviewers can be more personal with their intentions, but the infamous Reviewer 2 will always be around the corner. The industries will probably pay you handsomely, but there is a grey zone that can be quite nerving to think about. Oh, and the public. The public. It is hard to know their needs. The scientific contribution needs to be understandable, but cheap. It must be practical, but it should work on the first try.

So, it is quite a mess. And I understand we all want to point the finger, and curse someone for our misery. However, as The Godfather said, you should not apologize for your life, for taking care of your family.

The quest to dance perfectly on the strings will always be one of the challenges that scientists must face. In developed countries, the academic system has developed enough to provide a certain degree of stability to researchers [1]. Even though they are still being driven by golden eggs [2], a sense of devotion and respect is still laid within that academia, that it is hard to ignore its contribution. Thus, the criticism toward the system feels constructive [3-5].

On the contrary, in a country like Vietnam, where the basic monthly salary is only around 5 million Vietnamese Dong, you cannot just ask people to fund million US dollars for your research [6]. Science is often being scrutinized, and without an immediate effect, the public can quickly deem such science useless. Thus, in a way, the publication is a visible option for the scientists to advertise their abilities. 
"So, you are a scientist. What do you actually do?"

"Hey, here are my papers. Just take a look for yourself."

It is an easy way out, and especially effective in sending people away (even though start explaining your research also sends people away instantly). Nonetheless, experts suggested that the motivation to publish scientific papers can have a good effect on the mindset of Vietnamese researchers, for now [7]. Early career researchers and women can benefit from this, as the battleground is still peaceful.

However, what will be waiting for the researchers?

The 'ask-give' mechanism of science is unsustainable. The researchers will always have to rely on universities and funders. Even though they have been generous, it is hard to fathom the irrational cost of modern science, especially when it comes to scientific publishing. Thus, the business of science, or entrepreneurial science, can be a viable option. Ho et al. [8] defined the business of science as "a business where research and research-based activities and contents are the products." So, it is a good place to start. In fact, in certain fields, scientists have been achieving great success with the entrepreneurial model. For instance, Moderna-one of the first companies to deliver the COVID-19 vaccine-is the brainchild of MIT chemist-entrepreneur Robert Langer [9].

However, it is easy to imagine a medical invention and product. Heavily theoretical fields such as mathematics, philosophy, or even social sciences in general, will have a hard time finding a marketable product. Even among the traditional system, these disciplines could be neglected and underfunded. Thus, it would be a serious question for researchers to figure out. If researchers cannot figure it out, who can?

In the traditional system, universities and funders also have the role of quality assurance. They are the watchmen to ensure that the scientists will not cross the ethical boundary. However, the newfound freedom from entrepreneurial science can be quite sinful. So, who will watch the researchers now? The publishing entities use retractions as a guarding tool [10]. Nonetheless, anything wrong should be prevented rather than treated. Researchers, therefore, will be on an even higher moral ground than before.

Ironically, despite a viable option to seek freedom in the business of science, researchers seem to continue dancing on the strings, just with different big shots. It will be a long journey for researchers to find the right path.

"Well, there wasn't enough time, Michael. There just wasn't enough time." -Don Vito Corleone-

Ah yes, time is also a big shot.

\section{References}


[1] Labaree, D. (2017). An unlikely triumph. Aeon. Retrieved from https://aeon.co/essays/how-the-us-college-went-from-pitiful-to-powerful

[2] Labaree, D. (2018). Gold among the dross. Aeon. Retrieved from https://aeon.co/essays/higher-education-in-the-us-is-driven-by-a-lust-for-glory

[3] Bartle, T. (2019). Your CV does not define you. Nature Human Behaviour, 3, 1002, DOI: 10.1038/s41562-019-0736-x

[4] Kiai, A. (2019). To protect credibility in science, banish "publish or perish". Nature Human Behaviour, 3, 1017-1018, DOI: 10.1038/s41562-019-0741-0

[5] Chatterjee, D. (2019) Bean counting ignores structural inequalities. Nature Human Behaviour, 3, 1003-1004, DOI: 10.1038/s41562-019-0680-9

[6] Vuong, Q. H. (2018). The (ir)rational consideration of the cost of science in transition economies. Nature Human Behaviour, 2(1), 5.

[7] Vuong, Q. H. (2019). Breaking barriers in publishing demands a proactive attitude. Nature Human Behaviour, 3(10), 1034.

[8] Ho, M. T., Hoang, K. L., Nguyen, M. H., Ho. M. T., (2019). Chapter 8. The emerging business of science in Vietnam. In Quan-Hoang Vuong, Trung Tran (Eds.), The Vietnamese Social Sciences at a Fork in the Road (pp. 163-177). Warsaw, Poland: Sciendo. DOI: 10.2478/9783110686081-013

[9] Dayton, L. (2020). Coronavirus vaccine front-runner Moderna puts MIT chemistentrepreneur Robert Langer in the spotlight. Nature Index. Retrieved from https://www.natureindex.com/news-blog/coronavirus-vaccine-front-runnermoderna-puts-mit-chemist-entrepreneur-robert-langer-in-the-spotlight

[10] Vuong, Q. H. (2020). Reform retractions to make them more transparent. Nature, 582(7811), 149. 